\title{
The Voltammetry of Decamethylferrocene and Coboltacene in Supercritical Difluoromethane (R32)
}

\author{
P. N. Bartlett and J. Branch \\ Chemistry, University of Southampton, Southampton, SO17 1BJ, UK
}

\begin{abstract}
The voltammetry of decamethylferrocene, cobaltocene and decamethylcobaltocene at micro and macro disc electrodes in supercritical difluoromethane at $360 \mathrm{~K}$ and 17.6 MPa has been studied. In all cases the voltammetry is distorted to some degree by the effects of random convection but these can be supressed by adding a baffle around the electrode. The voltammetry of decamethylferrocene is well behaved with fast electrode kinetics at Pt microdisc electrodes. The limiting currents, corrected for random convection, obey the normal microdisc equation and are linear in electrode radius for decamethylferrocene up to the highest concentration $(11 \mathrm{mM})$ used in this study. Based on the microelectrode studies, we find that the diffusion coefficient of decamethylferrocene in supercritical difluoromethane containing $20 \mathrm{mM}\left[\mathrm{NBu}_{4}^{\mathrm{n}}\right]\left[\mathrm{BF}_{4}\right]$ at $360 \mathrm{~K}$ and $17.6 \mathrm{MPa}$ is $8.3 \times 10^{-5} \mathrm{~cm}^{2} \mathrm{~s}^{-1}$. Finally we have briefly investigated the voltammetry of cobaltocene and decamethylcobaltocene in supercritical difluoromethane under the same conditions. We find that reduction of the cobaltocenium cation leads to fouling of the Pt microdisc electrode which limits its use as a model redox system and that reduction of the decamethylcobaltocenium cation was not observed before electrolyte reduction at around $-1.6 \mathrm{~V} v s$. Pt.
\end{abstract}

\section{Introduction}

Supercritical fluids are interesting solvents in which to carry out electrochemistry because of their unique combination of properties that fall between those of liquids and those of gases. However because of the difficulties of working at elevated pressures they have not been that widely studied or used in electrochemistry [1,2]. Recent studies have shown that supercritical fluids are of interest for electrodeposition [3-7], electrosynthesis [8-10], and as media for the electrochemical reduction of carbon dioxide [11-13]. This interest arises because of the combination of low viscosity, high mass transport rates, the absence of surface tension and the wide potential window that supercritical electrolytes can offer combined with the opportunity to tune their solvent properties by control of the temperature and pressure. 
Metallocenes are obvious choices as model redox probe species for studies of electrochemistry in supercritical fluids since they are available as neutral, and thus soluble in low dielectric solvent, fairly volatile species and are expected to undergo one electron outer-sphere redox reactions. For nonaqueous solutions the International Union of Pure and Applied Chemistry (IUPAC) recommends the use of the ferrocene/ferrocenium $\left(\mathrm{Fc} / \mathrm{Fc}^{+}\right)$redox couple [14-16] as an internal reference system. However this has been questioned [17] as some studies have shown that the $\mathrm{Fc}^{+}$ion can react with nucleophiles in some solutions and the decamethylferrocene/decamethylferrocenium ( $\left.\mathrm{DMFc} / \mathrm{DMFc}{ }^{+}\right)$ couple has been proposed [16] as a better choice. Here the bulky methyl groups on the two cyclopenadienyl rings are expected to sterically hinder specific and nonspecific interactions between solute and solvent molecules [17]. The electrochemistry of the DMFc/DMFc ${ }^{+}$couple has been studied by a number of groups under a range of conditions: the couple exhibits a reversible one electron redox process at the electrode with facile electron transfer kinetics [16-23]. Noviandri et al. [17] extensively studied the solvent dependences of the formal redox potential of the $\mathrm{Fc} / \mathrm{Fc}^{+}, \mathrm{DMFc} / \mathrm{DMFc}^{+}$and 1,2,3,4,5-pentamethyl-ferrocene $\left(\mathrm{Me}_{5} \mathrm{Fc}\right)$ couples in 29 solvents and concluded that $\mathrm{DMFc} / \mathrm{DMFc}^{+}$ satisfied the criteria required for a redox standard for use in non-aqueous solvents that complied with all of the IUPAC requirements.

The first studies of the electrochemistry of metallocenes in supercritical fluid were by Crooks and Bard [24] who investigated the electrochemistry of ferrocene in near-critical and supercritical acetonitrile $\left(\mathrm{scCH}_{3} \mathrm{CN}\right)$ between 298 and $573 \mathrm{~K}$. They found a reversible, or nearly reversible, oneelectron oxidation wave for ferrocene at low scan rates over the entire temperature range studied. At subcritical temperatures a simple one electron oxidation of $\mathrm{Fc}$ to $\mathrm{Fc}^{+}$was observed [24] but in experiments above $T_{\mathrm{C}}$ (the critical temperature for the solvent) there was evidence of mild filming of the electrode. Subsequently Cabrera and Bard [21] studied the electrochemistry of other organometallic complexes, including decamethylferrocene, in near and supercritical $\mathrm{CH}_{3} \mathrm{CN}$. Decamethylferrocene was found to show reversible or quasi-reversible behaviour from 298 to $555 \mathrm{~K}$ (into the supercritical region), and as the temperature increased the peak to peak potential separation increased due to increasing uncompensated resistance in the cell.

Other studies of ferrocene electrochemistry at $25 \mu \mathrm{m}$ Pt microdisc electrodes in supercritical chlorodifluoromethane $\left(\mathrm{scCHClF}_{2} ; T_{\mathrm{C}}=369.15 \mathrm{~K}\right.$ and $p_{\mathrm{C}}=4.97 \mathrm{MPa}, \varepsilon=2.31$ at the critical point) by Olsen and Tallman [25] showed a typical microelectrode response very similar to that found in the liquid solvent at $299 \mathrm{~K}$, although they did see some evidence for passivation of the electrode surface. Subsequently the same authors also investigated the voltammetry of ferrocene and cobaltocenium in liquid and $\mathrm{scCHClF}_{2}$ [26]. They concluded that ferrocene and colbaltocenium were excellent choices as potential references in $\mathrm{scCHClF}_{2}$ since the difference in their half-wave potentials was independent of pressure over a considerable range and only slightly, but predictably, dependent on temperature. 
Voltammetry of ferrocene was also performed in supercritical trifluoromethane $\left(\mathrm{scCHF}_{3}\right)$ where reversible Nernstian behaviour was observed [26]. Goldfarb and Corti [27, 28] studied the electrochemistry of DMFc and decamethylferrocenium hexafluorophosphate $\left(\mathrm{DMFc}^{+}\right)$in $\mathrm{scCHF}_{3}$ using linear sweep voltammetry at $25 \mu \mathrm{m}$ platinum microelectrodes at $323 \mathrm{~K}$ at several densities with and without supporting electrolyte (tetrabutylammonium hexafluorophosphate). It was found that $\mathrm{DMFc}^{+}$voltammetry was strongly influenced by the concentration of supporting electrolyte - with a decrease in concentration of supporting electrolyte causing an increase in the limiting current for $\mathrm{DMFc}^{+}$reduction due to the effects of migration [27].

Decamethylferrocene (DMFc) has also been used as a probe redox couple in supercritical carbon dioxide with acetonitrile co-solvent $\left(\mathrm{scCO}_{2} / \mathrm{CH}_{3} \mathrm{CN}\right)$. Toghill et al. [11] using up to 0.41 mole fraction $\mathrm{CH}_{3} \mathrm{CN}$ and tetradecylammounium tetrakis(pentafluorophenyl)borate (TDATFPB, a room temperature ionic liquid) as the supporting electrolyte suggested that the electrochemistry occurred in a liquid-like $\mathrm{CH}_{3} \mathrm{CN}$ phase formed at the electrode surface. In contrast, we [29] found well behaved voltammetry for the same redox couple in $\mathrm{scCO}_{2} / \mathrm{MeCN}$ containing around $15 \mathrm{wt} \%$ (0.17 mole fraction) $\mathrm{CH}_{3} \mathrm{CN}$ with no evidence for a liquid film at the electrode surface.

The cobaltocenium, $\mathrm{CoCp}^{+}$, couple is isoelectronic with ferrocene and also expected to show ideal reversible, one-electron electrochemistry [15]. The cobaltocenium $\left(\mathrm{CoCp}^{+} / \mathrm{CoCp}_{2}\right)$ redox couple has a formal redox potential that is sufficiently separated from $\mathrm{DMFc}_{\mathrm{DMFc}}{ }^{+}$to allow the two couples to be investigated in the same solution without interference. Stojanovic and Bond [30] examined the $\mathrm{CoCp}_{2}{ }^{+} / \mathrm{CoCp}_{2}$ couple with respect to the $\mathrm{Fc} / \mathrm{Fc}^{+}$couple and found that the measured half-wave potential separation between the two couples was essentially independent of electrode material, electrolyte and solvent [30]. In contrast, the half-wave potential for the $\mathrm{CoCp}_{2}{ }^{+} / \mathrm{CoCp}_{2}$ couple when used in isolation was found to be considerably more solvent dependent and could not always be accurately measured at $25^{\circ} \mathrm{C}$ because of overlap with the "solvent" response and for "a range of other reasons" [30]. To overcome this problem, the fully methylated version of the compound decamethylcobaltocene $\left(\mathrm{DMCc}^{+}\right)$has been investigated. Aranzaes et al. [31] made measurements of the redox potential $\left(E_{1 / 2}\right)$ of a variety of metallocenes (including $\mathrm{DMFc}$ and $\mathrm{DMCc}^{+}$) in a range of solvents (including acetonitrile and dichloromethane). They found that the difference in $E_{1 / 2}$ values between $\mathrm{DMFc}$ and $\mathrm{DMCc}^{+}$was solvent independent [31].

In this paper we describe the results of experiments performed using DMFc as a model redox system in supercritical difluoromethane (scR32) at both micro and macro electrodes and compare the results to those of our earlier work in $\mathrm{scCO}_{2} / \mathrm{MeCN}$ [29]. We also report preliminary results for the electrochemistry of cobaltocene and decamethylcobaltocene in scR32. 


\section{EXPERIMENTAL}

\subsection{Reagents}

Difluoromethane $\left(\mathrm{CH}_{2} \mathrm{~F}_{2}\right.$, Apollo Scientific Ltd., 99\%) was used as received with no further purification. The supporting electrolyte tetrabutylammonium tetrafluoroborate $\left(\left[\mathrm{NBu}_{4}{ }_{4}\right]\left[\mathrm{BF}_{4}\right]\right.$, Aldrich, 99\%) was used as received. Decamethylferrocene (DMFc, $\mathrm{C}_{20} \mathrm{H}_{30} \mathrm{Fe}$, Aldrich, 97\%), decamethylcobaltocene $\left(\mathrm{C}_{20} \mathrm{H}_{30} \mathrm{Co}\right.$, Aldrich) and decamethylcobaltocenium hexafluorophosphate $\left(\left[\mathrm{C}_{20} \mathrm{H}_{30} \mathrm{Co}\right]^{+}\left[\mathrm{PF}_{6}\right]^{-}\right.$, Aldrich, $\left.98 \%\right)$ were all sublimed prior to use. Cobaltocenium hexafluorophosphate $\left(\left[\mathrm{C}_{10} \mathrm{H}_{10} \mathrm{Co}\right]^{+}\left[\mathrm{PF}_{6}\right]^{-}\right.$, Aldrich, $\left.98 \%\right)$ was used as received.

\subsection{Electrodes for Supercritical Fluids}

The working electrodes were platinum wires of varying size $(10-500 \mu \mathrm{m}$ diameter, Goodfellow, Advent Research Materials Ltd.) and gold macrodiscs which were either sealed in glass or in polyether-ether ketone (PEEK, Supelco, Thames Restek, Upchurch Scientific, Vici) 1/16" tubing. All electrodes were polished prior to each experiment on a polishing cloth (12" microcloth, Buehler) with alumina paste $(1 \mu \mathrm{m}$ followed by $0.3 \mu \mathrm{m}$ average particle diameter). All electrodes were sealed in PEEK (1.6 mm diameter OD, 0.5 - $1 \mathrm{~mm}$ ID, Supelco.) tubing with bisphenol A epoxy resin (EpoFix kit, Struers). Gold (0.5 mm Ø) macrodiscs along with platinum (10-50 $\mu \mathrm{m} \varnothing)$ microdiscs were used as working electrodes. For supercritical experiments using microwires, the microwires were directly contacted to a $250 \mu \mathrm{m}$ diameter $\mathrm{NiCr}$ wire in a soda glass capillary, the whole section was then sealed further in PEEK. Platinum wires $(0.5 \mathrm{~mm} \varnothing)$ were used for both counter and pseudo reference electrodes; these were sealed in PEEK as previously described.

\subsection{Cell Design}

All the high pressure electrochemical experiments were carried out with the use of a $316 \mathrm{~L}$ stainless steel reactor. This cell is specially designed and has been described in the literature [32]. The steel cell consists of two parts, the top part contains seven 1/16 inch female SSI type fittings through which a thermocouple, a $\mathrm{CO}_{2} / \mathrm{R} 32$ feeding line and the 5 electrodes could be fed and sealed. The last port is used for the safety key which makes the final seal. The bottom part contains an $8.65 \mathrm{~mL}$ working volume where the solution is confined after pressurisation, along with an area for the O-ring to be placed. The two parts of the cell were held together with a belt clamp and safety seal, Figures 1 and 2 . 


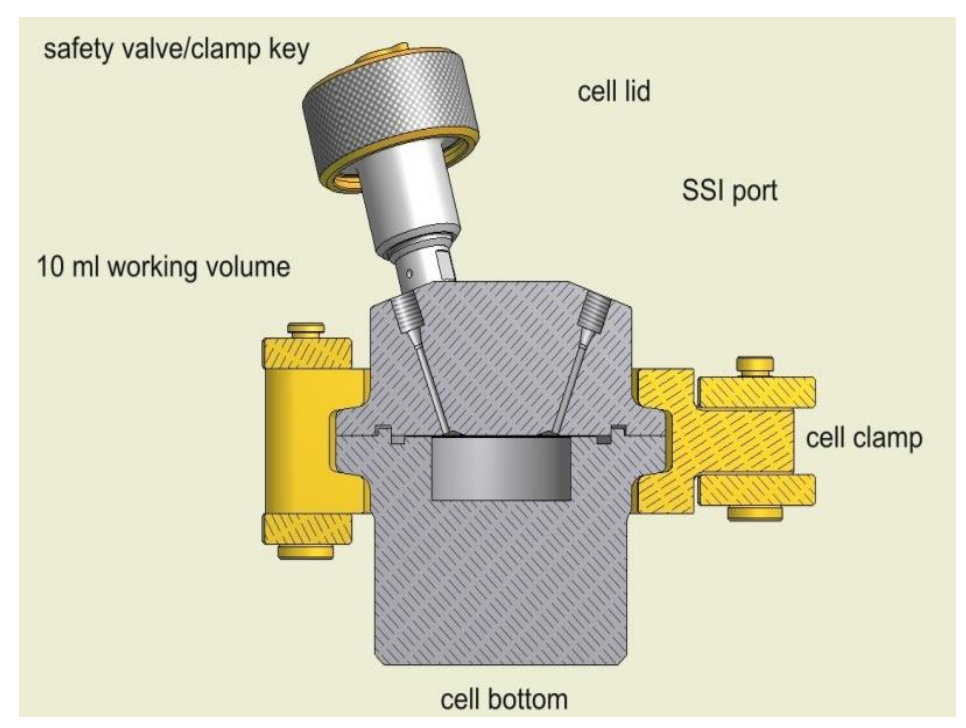

Fig. 1. Schematic of the high pressure reactor. Courtesy of the Engineering workshop of the School of Physics and Astronomy, University of Southampton, UK.

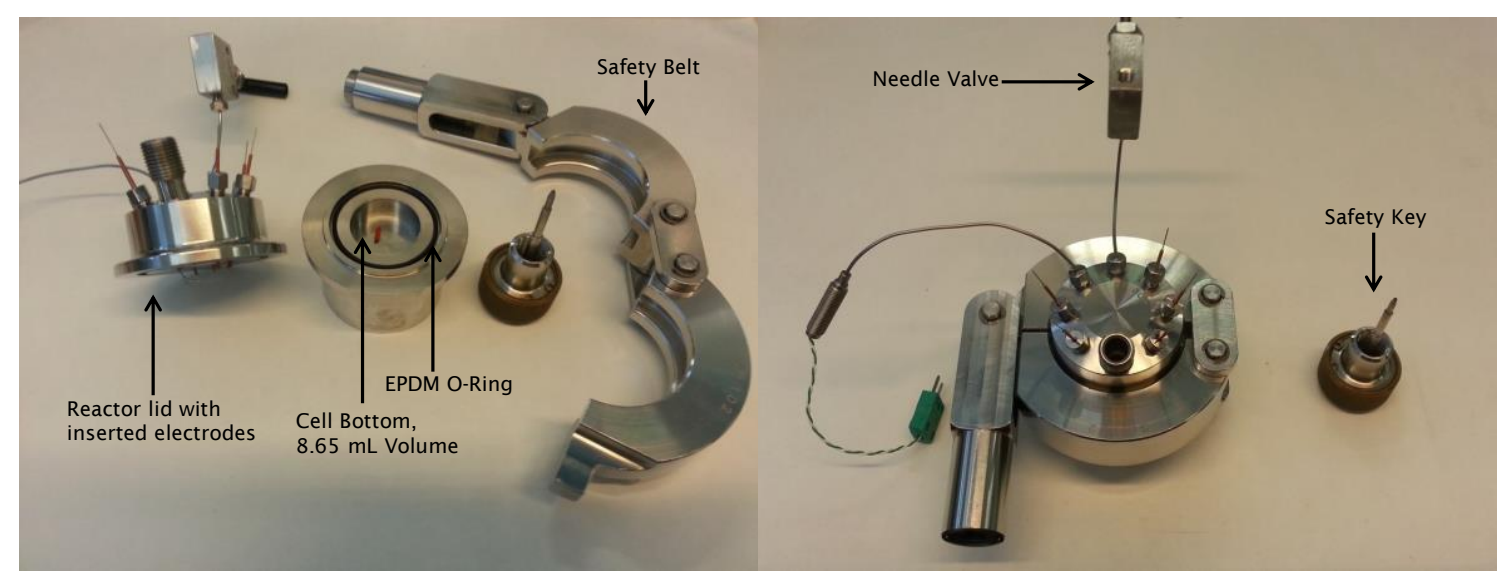

Fig. 2. Picture of the dismantled (left) and sealed steel cell (right).

\subsection{Procedure}

Electrolytes and metallocenes were introduced into the cell as dry powders. This loading step was carried out in a dry, dinitrogen purged glove box when air sensitive materials were employed. To introduce the metallocenes into the supercritical cell, small quantities of the solid were weighed out and then transferred to the $\mathrm{N}_{2}$ purged glove box. The powders were then introduced into the cell in the glove box.

A JASCO PU-1580- $\mathrm{CO}_{2}$ pump (left under cylinder pressure, 1.1 MPa) was used to introduce liquid R32 into the cell. The working pressure ranged from 17.2 - 17.6 MPa. The contents of the cell were stirred during pumping with a PTFE magnetic stirrer bar with an IKA® RCT basic heater/stirrer. The 
internal temperature of the cell was measured in situ using a thermocouple sealed in the cell and connected to a standard portable thermometer (ST-9612 thermometer). The cell was heated by an insulated band heater (Omega) and the temperature regulated by a bench-top homemade controller, which received feedback from a thermocouple mounted in a hole of an aluminium jacket at the bottom of the cell throughout the duration of the experiment. The electrochemical data were obtained using a PGSTAT101 with NOVA software. R32 was delivered through 1/16 inch high pressure tubing and an open HIP needle valve (Staffordshire Hydraulics Services Ltd.) to the JASCO pump, where it is cooled. The rate of pumping was set manually to $2 \mathrm{ml} \mathrm{min}^{-1}$, as the pressure is increased this was reduced to 1, 0.5, 0.2 and finally $0.1 \mathrm{ml} \mathrm{min}^{-1}$ until the desired pressure (max $20.7 \mathrm{MPa}$ ) was obtained. The pressure in the line was measured using a pressure transducer (model TJE, with E725 display, Honeywell). Upon completion, the contents of the cell were gradually depressurised through the use of a JASCO BP-1580-81 back pressure regulator.

\section{Results and Discussion}

\subsection{Electrochemistry of Decamethylferrocene in scR32 at Microelectrodes}

Figure 3 shows cyclic voltammetric data for DMFc in scR32 containing $20 \mathrm{mM}\left[\mathrm{NBu}_{4}{ }_{4}\right]\left[\mathrm{BF}_{4}\right]$ as the background electrolyte recorded at three different platinum microdisc electrodes. The data were obtained at $360 \mathrm{~K}$ and $~ 17.6 \mathrm{MPa}$. Studies of the phase behaviour and conductivity show that under these conditions the system is a single, supercritical phase [33]. Bartlett et al. [33] also showed that the molar conductivity of $\left[\mathrm{NBu}_{4}^{n}\right]\left[\mathrm{BF}_{4}\right](c=9 \mathrm{mM})$ is $0.0144 \mathrm{~S} \mathrm{~m}^{2} \mathrm{~mol}^{-1}$ at $26.0 \mathrm{MPa}$ and $363.15 \mathrm{~K}$, which is comparable to the result obtained by Abbott and Eardley in a similar system $\left(0.013 \mathrm{~S} \mathrm{~m}^{2}\right.$ $\left.\mathrm{mol}^{-1}\right)$.

In all cases the limiting current on the sigmoidal wave shows significant noise due to random convection within the cell. These effects are similar to, although much smaller than, the effects of ultrasound on the current at microelectrodes [34]. The effect is more significant the larger the microelectrode as expected because the steady state diffusion layer thickness at the larger electrode is more extensive and hence more vulnerable to perturbation by convection. Amatore et al. [35, 36] have analysed the effects of natural convection at microdisc electrodes and showed that the effects increase with electrode radius. Based on their model we estimate, from the results in Figure 3, that the stagnant boundary layer at the electrode surface is around $35 \mu \mathrm{m}$ thick. Random convection is not normally a significant problem for microdisc measurements in liquids but supercritical fluids have lower viscosities ( 10 times less than for water) so convection effects are greater. In addition the density of a supercritical fluid is strongly dependent on temperature and pressure near the critical 
point and inhomogeneities in the temperature distribution in the heated high pressure cell may also contribute to driving convection.

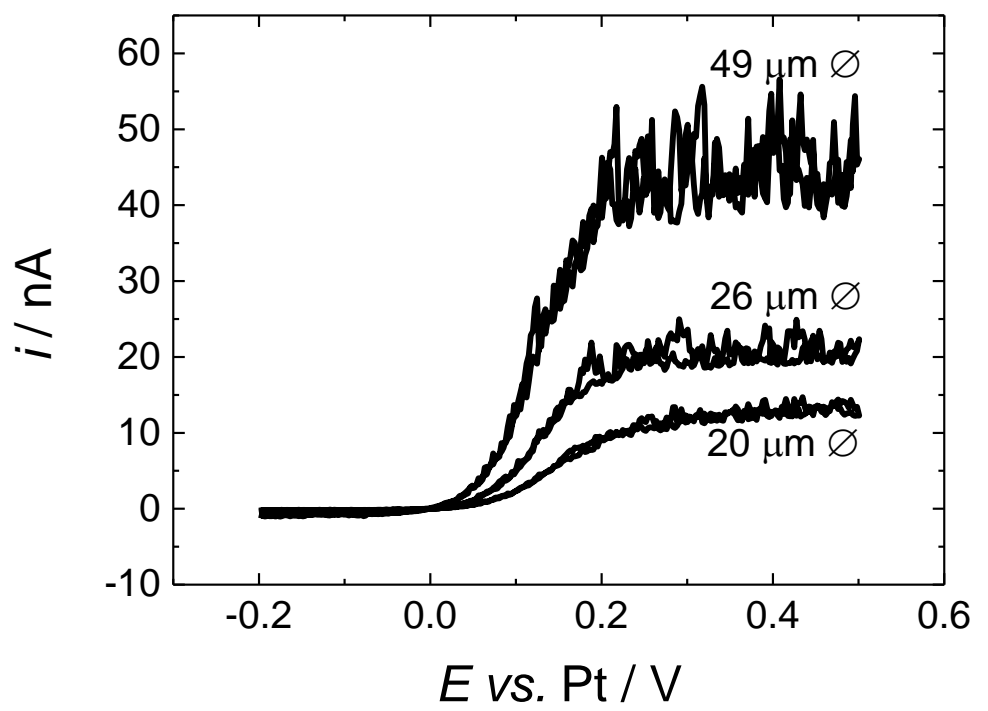

Fig. 3. Cyclic voltammograms for a solution containing $0.53 \mathrm{mM} \mathrm{DMFc}$ and $20 \mathrm{mM}\left[\mathrm{NBu}^{n}{ }_{4}\right]\left[\mathrm{BF}_{4}\right]$ in $\mathrm{scR} 32$, recorded at $10 \mathrm{mV} \mathrm{s}^{-1}, 360 \mathrm{~K}$ and $\sim 17.6 \mathrm{MPa}$. The reference and counter electrodes were 0.5 $\mathrm{mm} \emptyset \mathrm{Pt}$ wires. The working electrodes were $20 \mu \mathrm{m}, 26 \mu \mathrm{m}$ and $49 \mu \mathrm{m} \emptyset \mathrm{Pt}$ microdiscs.

The results seen here for scR32, for the effects of convection, are similar to those seen in previous work [29] in $\mathrm{scCO}_{2} / \mathrm{CH}_{3} \mathrm{CN}$. Figure 4 shows a comparison of the voltammetry of $0.2 \mathrm{mM} \mathrm{DMFc}$ in $\mathrm{scCO}_{2} / \mathrm{CH}_{3} \mathrm{CN}$ and scR32 at a $49 \mu \mathrm{m}$ electrode recorded in the same design of high pressure cell. It is notable that the effects of convection in scR32 are significantly greater than seen in $\mathrm{scCO}_{2} / \mathrm{CH}_{3} \mathrm{CN}$. We attribute the increased effect of random convection in scR32 to the higher temperature, $360 \mathrm{~K}$ as opposed to $313 \mathrm{~K}$, and the lower viscosity of the scR32 as compared to $\mathrm{scCO}_{2} / \mathrm{CH}_{3} \mathrm{CN}$. It is also clear from the direct comparison in Figure 4 that the limiting current obtained in scR32 is around twice that observed in $\mathrm{scCO}_{2} / \mathrm{MeCN}$ indicating that the diffusion coefficient of DMFc in scR32 is significantly larger than that in $\mathrm{scCO}_{2} / \mathrm{CH}_{3} \mathrm{CN}$, we return to this below. 


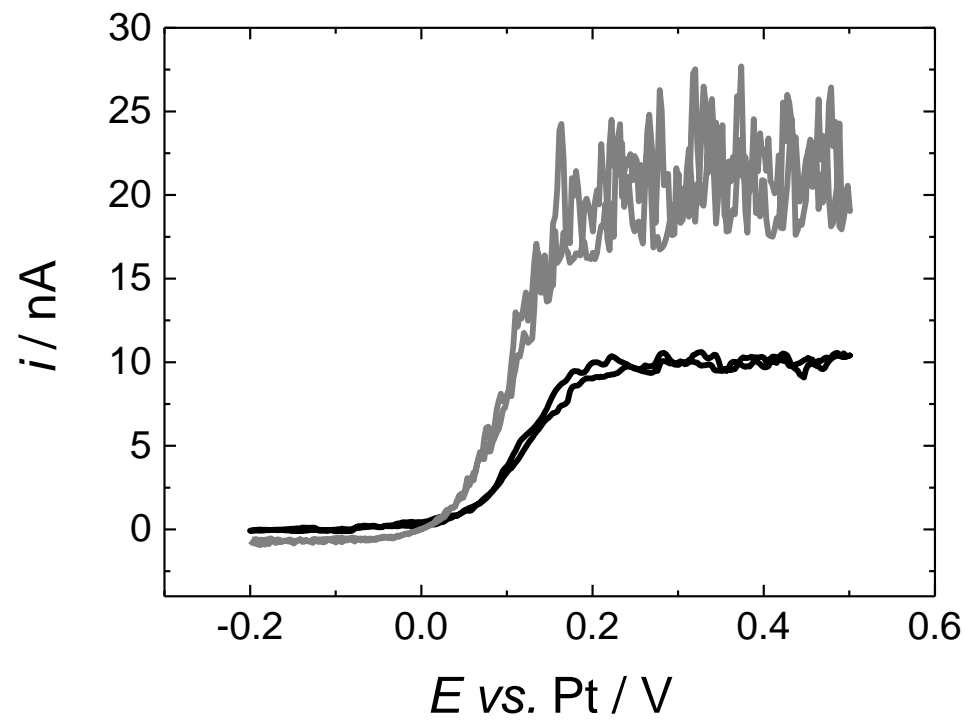

Fig. 4. Black line: Cyclic voltammetry for a solution containing $0.22 \mathrm{mM} \mathrm{DmFc}$ and $20 \mathrm{mM}\left[\mathrm{NBu}_{4}{ }_{4}\right]$ $\left[\mathrm{BF}_{4}\right]$ in $\mathrm{scCO}_{2} / \mathrm{MeCN}(15 \mathrm{wt} \%)$ at $313 \mathrm{~K}$ and $\sim 17.6 \mathrm{MPa}$. The working electrode was a $49.4 \mu \mathrm{m} \varnothing \mathrm{Pt}$ disc. Grey line: Cyclic voltammetry for a solution containing $0.2 \mathrm{mM} \mathrm{DmFc}$ and $20 \mathrm{mM}$ $\left[\mathrm{NBu}_{4}{ }^{n}\right]\left[\mathrm{BF}_{4}\right]$ in scR32 at $360 \mathrm{~K}$ and $\sim 17.6 \mathrm{MPa}$. The working electrode was a $49 \mu \mathrm{m} \varnothing \mathrm{Pt}$ disc. In both cases the scan rate was $10 \mathrm{mV} \mathrm{s}^{-1}$ and the reference and counter electrodes were $0.5 \mathrm{~mm} \emptyset \mathrm{Pt}$ wires.

\subsection{Electrochemistry of Decamethylferrocene in scR32 using a Microdisc Electrode with a Baffle}

In order to reduce the effects of random convection we surrounded the microdisc electrodes with a cylindrical baffle made from PEEK tubing. The baffle surrounds the insulating glass $(0.5 \mathrm{~mm} \varnothing)$ that encapsulates the microdisc and extends $5 \mathrm{~mm}$ beyond the face of the electrode. Cyclic voltammograms recorded in a solution of scR32 containing DMFc and $20 \mathrm{mM}\left[\mathrm{NBu}_{4}^{n}\right]\left[\mathrm{BF}_{4}\right]$ for nominally $25 \mu \mathrm{m}$ diameter Pt microdiscs with and without a baffle are shown in Figure 5. The data from the voltammetry is summarised in Table 1 .

From Table 1, we can see that there is good agreement between the values of the half-wave potential for the two electrodes, $E_{1 / 2} \sim 0.125 \mathrm{~V} v s$. Pt (the small difference between the two values is probably due to the Pt pseudo reference electrode). The difference between the half $\left(E_{1 / 2}\right)$ and quarter $\left(E_{1 / 4}\right)$, and between the three quarter $\left(E_{3 / 4}\right)$ and half-wave potentials are close to the expected $34 \mathrm{mV}$ for a reversible 1e reaction at $360 \mathrm{~K}$ [37]. Figure 6 shows mass transport corrected Tafel plots for the two voltammograms. The slopes are both close to the expected value of $32.24 \mathrm{~V}^{-1}$ for a 1e reaction at 360 $\mathrm{K}$, leading to the values of $n$ being close to 1 (Table 1). It can also be seen in Figure 6 that the plot for the electrode with the baffle is more linear compared to that for the electrode without the baffle where 
the currents are distorted by the random convection. Again, note that the small potential shift between the two plots is probably the result of slight drift in the Pt pseudo reference potential. The results indicate that the voltammetry in scR32 under these conditions is not distorted by $\mathrm{iR}$ drop. This is in contrast to the results in $\mathrm{scCO}_{2} / \mathrm{CH}_{3} \mathrm{CN}$ containing $20 \mathrm{mM}\left[\mathrm{NBu}_{4}{ }_{4}\right]\left[\mathrm{BF}_{4}\right]$ and $0.43 \mathrm{mM} \mathrm{DMFc}$ and is consistent with the differences in molar conductivity, $2.3 \mathrm{~S} \mathrm{~cm}^{2} \mathrm{~mol}^{-1}$ in $\mathrm{scCO}_{2} / \mathrm{CH}_{3} \mathrm{CN}$ compared to $124 \mathrm{~S} \mathrm{~cm}^{2} \mathrm{~mol}^{-1}$ in scR32 [33, 38].

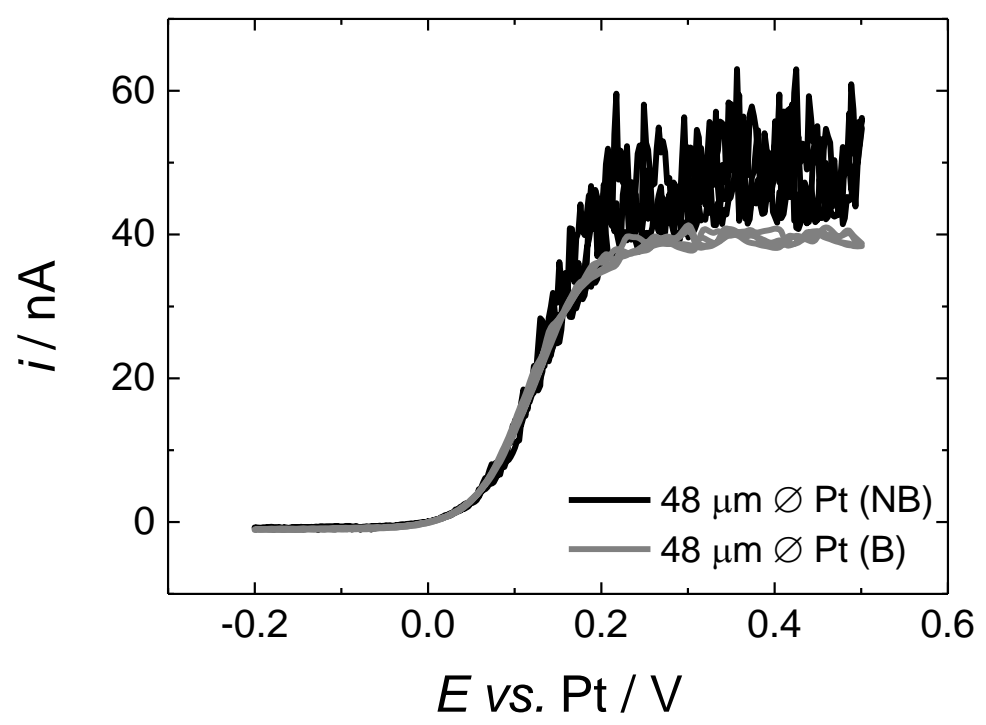

Fig. 5. Cyclic voltammograms for a solution containing $0.53 \mathrm{mM} \mathrm{DMFc}$ and $20 \mathrm{mM}\left[\mathrm{NBu}_{4}^{n}\right]\left[\mathrm{BF}_{4}\right]$ in scR32 recorded at $10 \mathrm{mV} \mathrm{s}^{-1}, 360 \mathrm{~K}$ and 18.0 MPa. The reference and counter electrodes were $0.5 \mathrm{~mm}$ $\varnothing \mathrm{Pt}$ wires. The working electrodes were $48 \mu \mathrm{m}$ (black, no baffle) and $48 \mu \mathrm{m}$ (grey, with baffle) $\varnothing \mathrm{Pt}$ microdiscs.

\section{Table 1.}

Cyclic voltammetry data obtained for experiments in $0.567 \mathrm{mM}$ DmFc with $20 \mathrm{mM}\left[\mathrm{NBu}_{4}{ }_{4}\right]\left[\mathrm{BF}_{4}\right]$ in scR32 $360 \mathrm{~K}$ and $17.6 \mathrm{MPa}$ recorded at $10 \mathrm{mV} \mathrm{s}^{-1}$ for two $24 \mu \mathrm{m}$ radius microdisc electrodes.

\begin{tabular}{|c|c|c|c|c|c|c|c|}
\hline $\begin{array}{l}24 \mu \mathrm{m} \\
\text { electrode }\end{array}$ & $\begin{array}{l}i_{\mathrm{L}} \\
/ \mathbf{n A}\end{array}$ & $\begin{array}{l}\Delta E_{(1 / 4-3 / 4)} \\
/ \mathrm{mV}\end{array}$ & $\begin{array}{l}E_{1 / 2} \\
/ V\end{array}$ & $\begin{array}{l}\Delta E_{1 / 4-1 / 2} \\
/ \mathrm{mV}\end{array}$ & $\begin{array}{l}\Delta E_{1 / 2-3 / 4} \\
/ \mathrm{mV}\end{array}$ & $\begin{array}{l}d \ln \left[\left(i_{\mathrm{L}} / i\right)-1\right] / d E \\
/ \mathrm{V}^{-1}\end{array}$ & $n$ \\
\hline no baffle & 39.4 & 59 & 0.127 & 32 & 27 & 36.0 & 1.1 \\
\hline with baffle & 37.6 & 66 & 0.120 & 34 & 32 & 34.6 & 1.1 \\
\hline
\end{tabular}




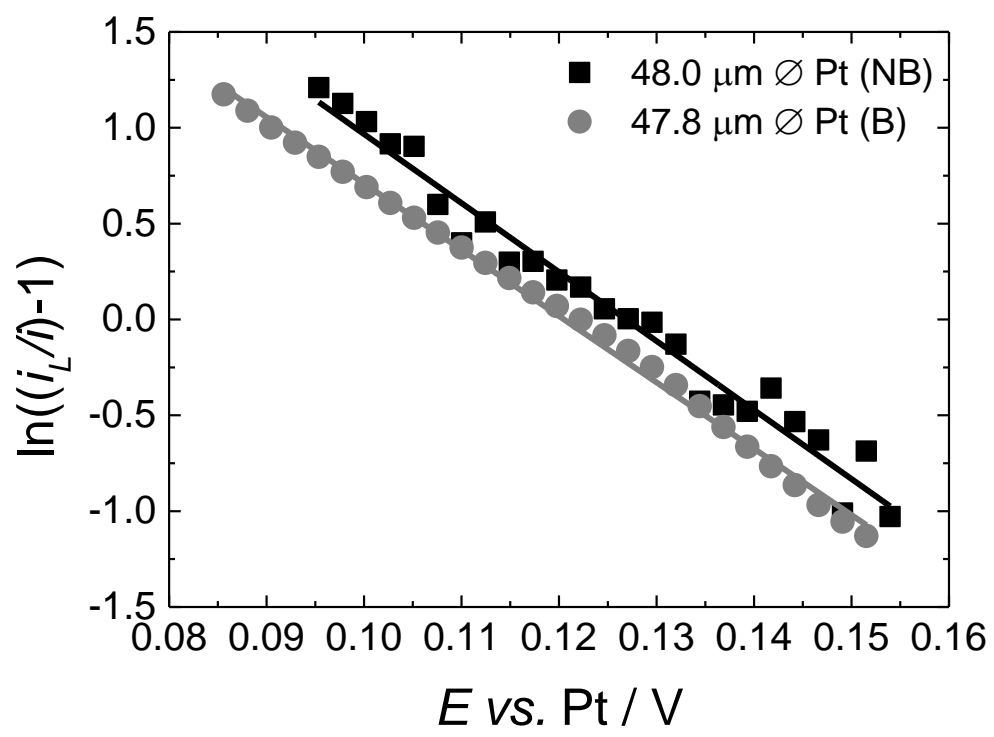

Fig. 6. Mass transport corrected Tafel analysis for microdisc voltammetry in $0.53 \mathrm{mM} \mathrm{DmFc}$ and $20 \mathrm{mM}\left[\mathrm{NBu}_{4}^{n}\right]\left[\mathrm{BF}_{4}\right]$ in scR32 at $10 \mathrm{mV} \mathrm{s}^{-1}, 360 \mathrm{~K}$ and $18.0 \mathrm{MPa}$. The microelectrodes were 48.0 and $47.84 \mu \mathrm{m} \varnothing \mathrm{Pt}$ discs $(\mathrm{NB}=$ no baffle; $\mathrm{B}=$ with baffle).

\subsection{Determination of the Diffusion Coefficient of Decamethylferrocene in scR32}

To obtain accurate values for the diffusion coefficient of DMFc in scR32 we investigated the voltammetry as a function of DMFc concentration as well as electrode diameter. Six concentrations of DMFc ranging from 0.2 to $11.2 \mathrm{mM}$ were investigated using three different microelectrodes (note that in the data below we only present results for 4 concentrations of DMFc at the smallest electrode, this is because in the course of the experiments the $\mathrm{NiCr}$ wire contact was exposed by polishing, rendering the electrode unusable). Figure 7 shows a plot obtained for the diffusion limited current against the concentration of DMFc for the three microdisc electrodes (Figure 7a) and against the electrode radii (Figure $7 b$ ). As discussed above, convective noise is a problem for determining the limiting current. To overcome this, the limiting current was taken from the lowest point of the convective noise as detailed in our previous publication [29]. As can be seen from Figure 7, the limiting current increases linearly with concentration and with electrode radius in all cases as anticipated from the limiting current expression for a microdisc electrode [39]

$$
i_{\mathrm{L}}=4 n F a D c
$$

where $i_{\mathrm{L}}$ is the mass transport limited current, $a$ the electrode radius, $c$ the concentration of the redox species and the remaining terms have their usual meanings. It is also clear from the plot that the solubility of DMFc in scR32 under these conditions exceeds $11 \mathrm{mM}$. 
From the slopes of the plots in Figures $7 \mathrm{a}$ and $\mathrm{b}$ we can obtain a value for the diffusion coefficient of DMFc using equation (1). These values are given in Table 2.
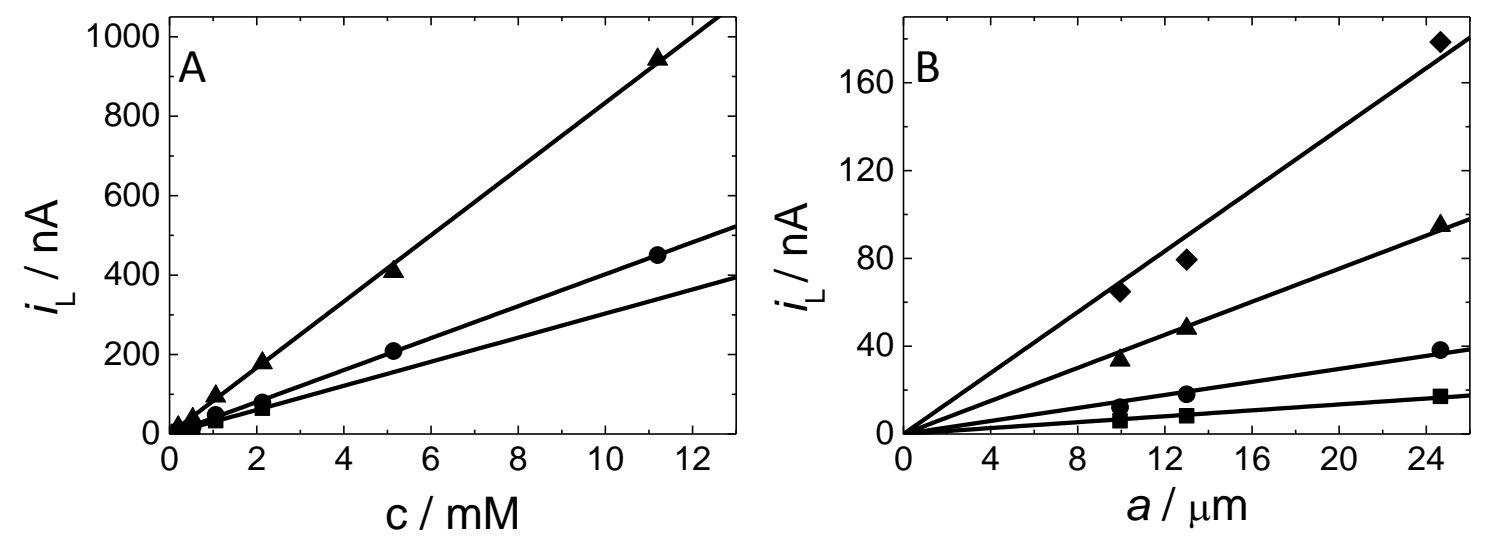

Fig. 7. a) Plot of diffusion limited current against the decamethylferrocene concentration (the working electrodes were a $19.9(\bullet), 26(\bullet)$ and $49.3 \mu \mathrm{m}(\mathbf{\Delta}) \varnothing$ Pt microdiscs) and b) against the electrode radius (concentrations were $0.2(\bullet), 0.53(\bullet), 1.06(\mathbf{\Delta})$ and $2.12 \mathrm{mM}(\bullet))$ for a series of cyclic voltammograms in scR32 and $20 \mathrm{mM}\left[\mathrm{NBu}_{4}{ }_{4}\right]\left[\mathrm{BF}_{4}\right]$ electrolyte at $360 \mathrm{~K}$ and 17.2 to $17.7 \mathrm{MPa}$. The counter and reference electrode were $0.5 \mathrm{~mm} \emptyset \mathrm{Pt}$ wires.

Table 2.

Variation of the diffusion coefficient with concentration of DMFc and electrode radius. The counter and reference electrode were $0.5 \mathrm{~mm} \emptyset$ platinum wires. Solutions were scR32, $20 \mathrm{mM}\left[\mathrm{NBu}_{4}{ }_{4}\right]\left[\mathrm{BF}_{4}\right]$ at $360 \mathrm{~K}, 17.2$ to $17.7 \mathrm{MPa}$.

\begin{tabular}{|c|c|c|}
\hline$a / \mu \mathrm{m}$ & $D / \mathrm{cm}^{2} \mathrm{~s}^{-1}$ & $D_{\mathrm{av}} / \mathrm{cm}^{2} \mathrm{~s}^{-1}$ \\
\hline $9.9 \pm 0.1$ & $7.9 \times 10^{-5} \pm 0.046 \times 10^{-5}$ & \multirow{3}{*}{$8.23 \times 10^{-5} \pm 0.06 \times 10^{-5}$} \\
\hline $13.0 \pm 0.2$ & $8.02 \times 10^{-5} \pm 0.064 \times 10^{-5}$ & \\
\hline $24.7 \pm 0.4$ & $8.77 \times 10^{-5} \pm 0.070 \times 10^{-5}$ & \\
\hline$c / \mathbf{m M}$ & $D / \mathrm{cm}^{2} \mathrm{~s}^{-1}$ & $D_{\mathrm{av}} / \mathrm{cm}^{2} \mathrm{~s}^{-1}$ \\
\hline $0.2 \pm 0.018$ & $8.72 \times 10^{-5} \pm 0.79 \times 10^{-5}$ & \multirow{4}{*}{$8.42 \times 10^{-5} \pm 0.32 \times 10^{-5}$} \\
\hline $0.53 \pm 0.018$ & $7.24 \times 10^{-5} \pm 0.25 \times 10^{-5}$ & \\
\hline $1.06 \pm 0.018$ & $9.22 \times 10^{-5} \pm 0.16 \times 10^{-5}$ & \\
\hline $2.12 \pm 0.018$ & $8.48 \times 10^{-5} \pm 0.072 \times 10^{-5}$ & \\
\hline
\end{tabular}

From the two sets of experiments the diffusion coefficient for DMFc in scR32 at $360 \mathrm{~K}$ and $~ 17.6$ MPa is found to be $8.3 \times 10^{-5} \mathrm{~cm}^{2} \mathrm{~s}^{-1}$. This is significantly higher than the diffusion coefficient measured for DMFc in liquid dichloromethane containing $0.5 \mathrm{M}$ TBAP at $298 \mathrm{~K}\left(D=1.03 \times 10^{-5} \mathrm{~cm}^{2}\right.$ 
$\mathrm{s}^{-1}$ ) as determined by Matsumoto et al. [40]. The diffusion coefficient for solutes in supercritical fluids depends on both pressure and temperature, because these affect the viscosity and because it is an activated process, so direct comparison with values in the literature is not straightforward. However, our value for the diffusion coefficient for DMFc is in the same range as values for ferrocene [24, 25] and DMFc [21, 28] in various supercritical fluids. Stokes-Einstein [26] and Wilke-Chang [41] models have both been applied to model diffusion coefficients in supercritical fluids. Using the StokesEinstein equation

$$
D=\frac{k_{\mathrm{B}} T}{6 \pi \eta a}
$$

where $\eta$ is the solvent viscosity and $a$ the hydrodynamic radius of the solute. Substituting values into equation (2), taking the hydrodynamic radius of DMFc as $0.480 \mathrm{~nm}$ [40], gives a value for the viscosity of the solvent as $66 \mu \mathrm{Pa}$ s. On the other hand if we use the Wilke-Chang equation [41]

$$
D=\frac{\left(7.4 \times 10^{-15}\right) T \sqrt{M}}{\eta(1.3 \times V)^{0.6}}
$$

where $M$ is the molecular weight of the solvent $\left(52 \mathrm{~g} \mathrm{~mol}^{-1}\right.$ for R32) and $V$ is the molar volume of the solute $\left(186.6 \mathrm{~cm}^{3} \mathrm{~mol}^{-1}\right.$ based on the van der Waals volume [42]) we obtain a value for the solution viscosity of $86 \mu \mathrm{Pa}$ s. These two values are close to the calculated value for the viscosity of scR32 at $360 \mathrm{~K}$ and 17.6 MPa from the NIST website [43] of $75 \mu \mathrm{Pa}$ s. This agreement should be regarded with caution since it takes no account of the effect of the electrolyte on the solution viscosity although work by Abbott et al. [44] suggests that at pressures well above $p_{\mathrm{c}}$, as used here, the effect of solutes should be small.

\subsection{Electrochemistry of Decamethylferrocene in scR32 at Macroelectrodes}

Cyclic voltammetry for a macroelectrode at various scan rates was also carried out to examine the behaviour of the couple in scR32 with $\left[\mathrm{NBu}_{4}{ }_{4}\right]\left[\mathrm{BF}_{4}\right]$ as supporting electrolyte. Voltammograms were recorded at a $1 \mathrm{~mm} \varnothing \mathrm{Au}$ disc in a solution of scR32 containing $0.39 \mathrm{mM} \mathrm{DMFc}$ and $20 \mathrm{mM}$ $\left[\mathrm{NBu}^{n}{ }_{4}\right]\left[\mathrm{BF}_{4}\right]$ at $360 \mathrm{~K}$ and $17.6 \mathrm{MPa}$, Figure 8 . It is clear that the voltammograms are significantly distorted by the random convection within the cell leading to noise and increased current at anodic potentials. This contrasts with the behaviour seen in $\mathrm{scCO}_{2} / \mathrm{MeCN}$ where the voltammograms were more affected by $i R$ than convection and arises because in scR32 the electrolyte conductivity is higher but the viscosity is lower. To reduce the effects of convection, a baffle electrode was constructed as outlined above. 


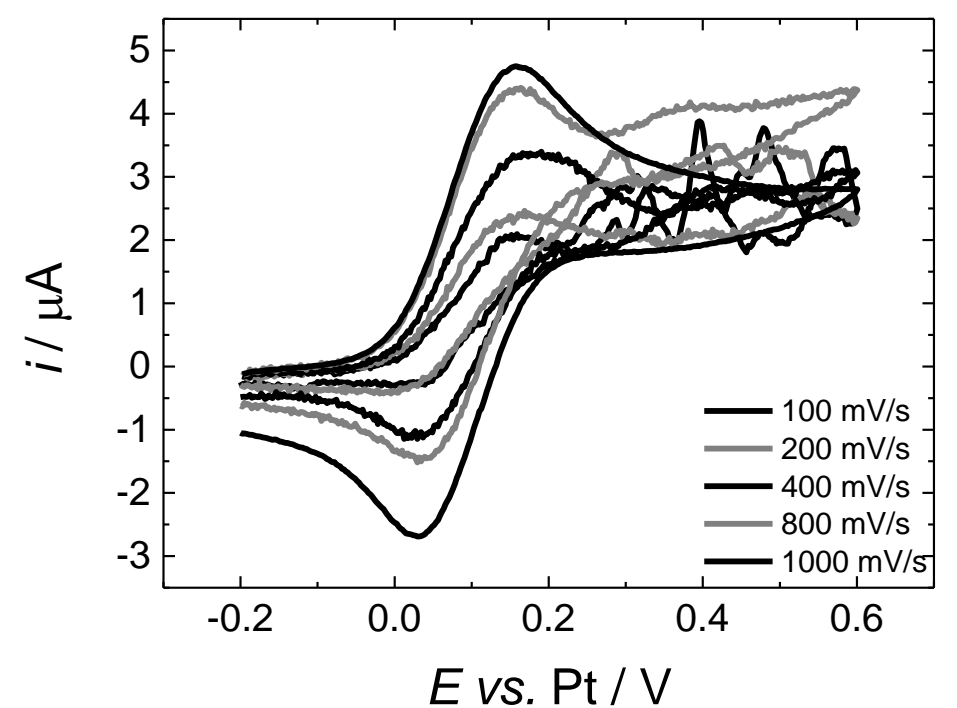

Fig. 8. Cyclic voltammograms at a range of scan rates for a solution of $0.39 \mathrm{mM} \mathrm{DmFc}$ and $20 \mathrm{mM}$ $\left[\mathrm{NBu}_{4}{ }_{4}\right]\left[\mathrm{BF}_{4}\right]$ in scR32 at $360 \mathrm{~K}$ and $17.6 \mathrm{MPa}$. The working electrode was a $1 \mathrm{~mm} \varnothing \mathrm{Au}$ disc, the reference and counter electrode were $0.5 \mathrm{~mm} \emptyset \mathrm{Pt}$ wires.

Cyclic voltammograms performed in a solution of scR32 for a $1 \mathrm{~mm} \varnothing$ Au disc fitted with a baffle are shown in Figure 9. It is clear from Figure 9 that the macroelectrode with the baffle shows well defined voltammetry with much less obvious influence of convection. The ratio of the anodic and cathodic peak currents is close to unity for all scan rates as expected. The effects of some iR drop can be seen in Figure 9 where the peak separation increases from 154 to $202 \mathrm{mV}$ with increasing scan rate. Similar behaviour and peak to peak potential separations were seen in liquid DCM. In this case the uncompensated solution resistance was estimated to be $\sim 13 \mathrm{k} \Omega$ which is reasonable given the known conductivity for this electrolyte [33]. 


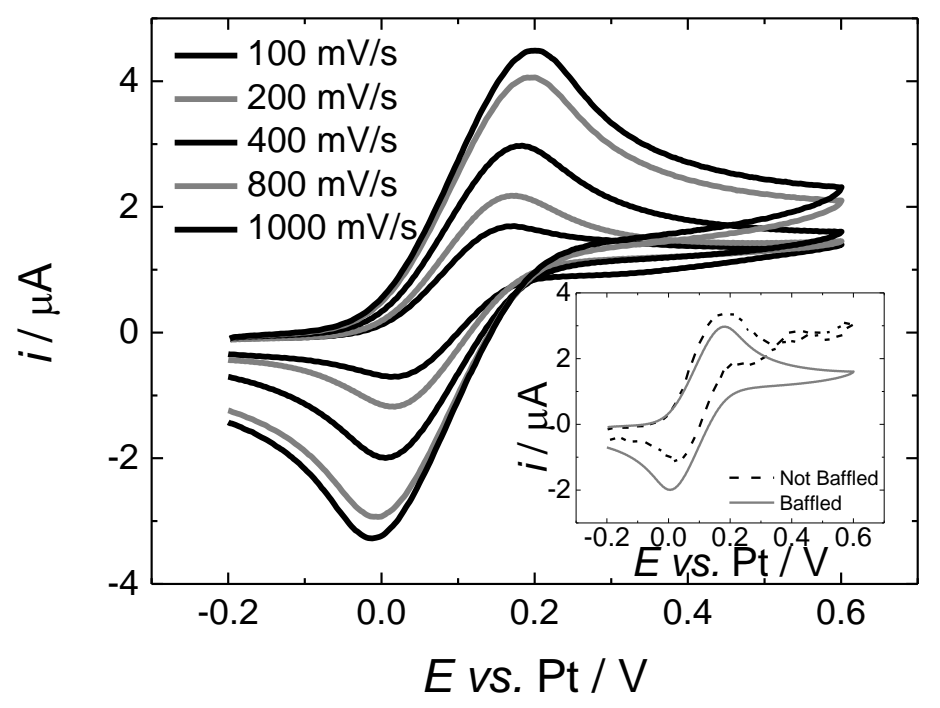

Fig. 9. Cyclic voltammograms at a range of scan rates for a solution of $0.39 \mathrm{mM} \mathrm{DmFc}$ and $20 \mathrm{mM}$ $\left[\mathrm{NBu}_{4}{ }_{4}\right]\left[\mathrm{BF}_{4}\right]$ in scR32 at $360 \mathrm{~K}$ and $17.6 \mathrm{MPa}$. The working electrode was a $1 \mathrm{~mm} \varnothing \mathrm{Au}$ disc fitted with a baffle, the reference and counter electrode were $0.5 \mathrm{~mm} \emptyset \mathrm{Pt}$ wires. The inset shows cyclic voltammograms recorded at $400 \mathrm{mV} \mathrm{s}^{-1}$ at $1 \mathrm{~mm} \emptyset \mathrm{Au}$ disc electrodes with (blue line) and without (black line) a baffle.

The insert in Figure 9 shows a direct comparison of voltammetry of DMFc recorded at $0.4 \mathrm{~V} \mathrm{~s}^{-1}$ for macroelectrodes with and without a baffle in the same solution. As can been seen the effect of convection in the case of the electrode without the baffle is to increase the oxidation current and at the same time reduce the size of the reduction current on the return scan; without the baffle the voltammogram begins to look much more like the steady state wave seen at a microdisc electrode with forced convection.

Even with the baffle fitted the voltammetry at the macrodisc electrode is still distorted by the effects of convection as shown by the comparison between the experimental voltammograms and simulation, Figure 10. As a consequence of the combined effects of convection and $i R$ drop, although a plot of the anodic and cathodic peak currents against the square root of scan rate gives reasonable straight lines the application of the Randles-Sevčik equation is not a reliable way to calculate the diffusion coefficient for the DMFc. 


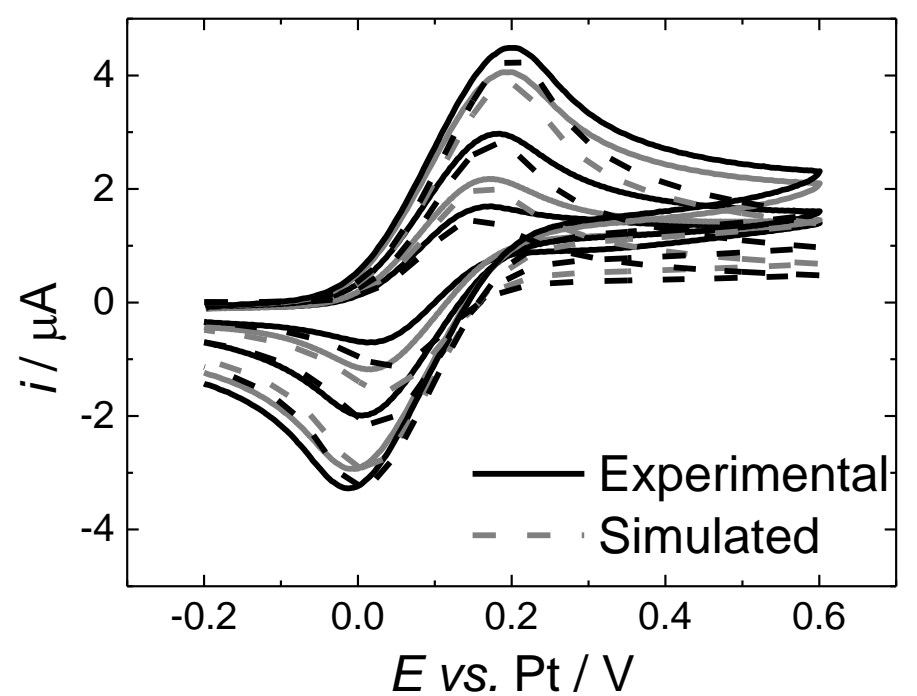

Fig. 10. Comparison of experimental and simulated voltammetry, the experimental details are given in Figure 9. The conditions used for the simulation (simulated using Digielch ${ }^{\mathrm{TM}} 7$ ) were $R=13 \mathrm{k} \Omega$, $D_{\text {ox }}$ and $D_{\text {Red }}$ were $5 \times 10^{-5}$ and $4 \times 10^{-5} \mathrm{~cm}^{2} \mathrm{~s}^{-1}$ respectively, $E^{\mathrm{O}}=0.1 \mathrm{~V}, A=0.00785 \mathrm{~cm}^{2}, k_{s}=10000$ $\mathrm{cm} \mathrm{s}^{-1}$ and $c=0.39 \mathrm{mM}$ and scan rates of $100,200,400,800$ and $1000 \mathrm{mV} \mathrm{s}^{-1}$. Black and grey are alternating scan rates with (-) representing experimental data and (- $)$ representing the simulated data.

\subsection{Cyclic Voltammetry of Cobaltocenes in Supercritical R32}

Both decamethylcobaltocene and cobaltocenium hexafluorophosphate are well behaved $1 \mathrm{e}^{-}$outer sphere redox species in $\mathrm{CH}_{3} \mathrm{CN}$ at both micro and macro electrodes [30, 31]. Decamethylcobaltocenium hexafluorophosphate has been shown to be a well behaved $1 \mathrm{e}^{-}$outer sphere redox species at both micro and macro electrodes in ionic liquids [45]. We were therefore interested to investigate the electrochemistry of these couples in scR32 as this would give couples with different molecular volumes, of interest to compare diffusion coefficients, and redox potentials.

Figure 11 shows typical cyclic voltammetry recorded for cobaltocenium hexafluorophosphate, $\left[\mathrm{CoCp}_{2}\right]\left[\mathrm{PF}_{6}\right]$, in scR32 containing $20 \mathrm{mM}\left[\mathrm{NBu}_{4}^{n}\right]\left[\mathrm{BF}_{4}\right]$ at a $50 \mu \mathrm{m}$ diameter Pt disc. The voltammogram clearly has the sigmoidal shape expected for a microdisc but compared to DMFc there is significant hysteresis between cathodic and anodic scans. The limiting current region again shows significant noise, due to the effects of random convection but, taking this into account, we can still obtain a reasonable estimate for the limiting current and hence an estimate for the diffusion coefficient of $1.0 \times 10^{-4} \mathrm{~cm}^{2} \mathrm{~s}^{-1}$. This value is close to the diffusion coefficient determined by Olsen and Tallman in $\mathrm{scCHClF}_{2}$ [26]. The slightly larger value than for $\mathrm{DMFc}$ is consistent with the smaller 
hydrodynamic radius for the cobaltocenium ion assuming there are no ion pairing effects. Although the voltammetry is reasonably well resolved on the first scan, subsequent scans show large distortion indicative of a highly resistive layer of some sort that eventually totally passivates the electrode. We were unable to remove this film by cycling to high anodic or cathodic potentials ( +3 to $-3 \mathrm{~V}$ ). At a higher concentration of $\left[\mathrm{CoCp}_{2}\right]\left[\mathrm{PF}_{6}\right](0.45 \mathrm{mM})$ and a lower scan rate, $10 \mathrm{mV} \mathrm{s}^{-1}$, the voltammetry at the microdisc passivated during the first cathodic scan, consistent with the deposition of some blocking layer on the electrode upon reduction of $\left[\mathrm{CoCp}_{2}\right]^{+}$.

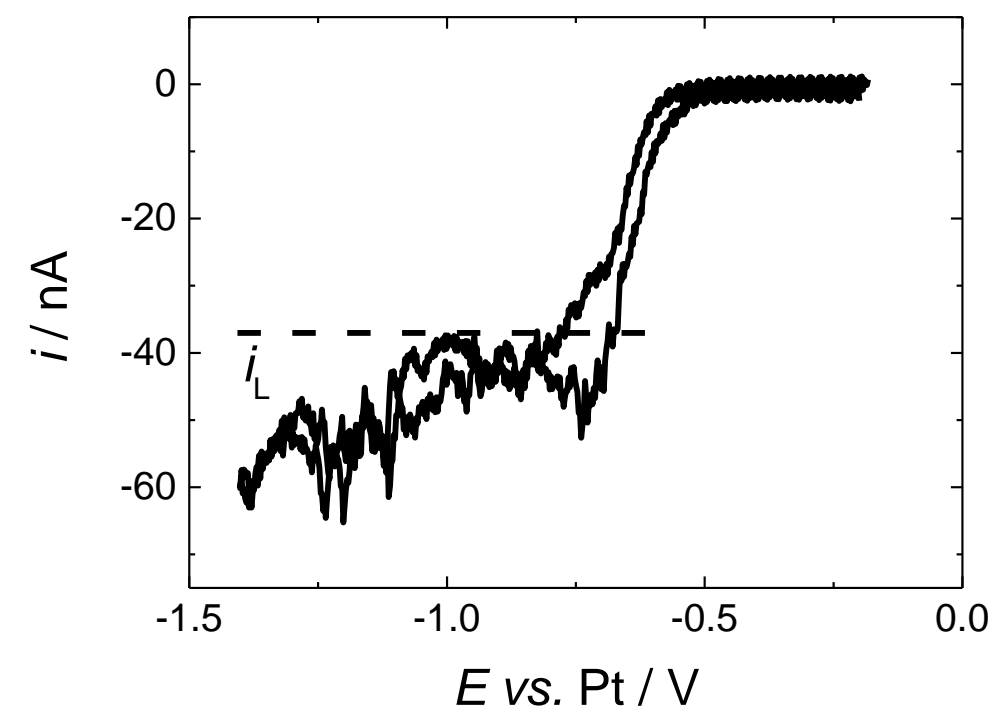

Fig. 11. Cyclic voltammetry for a solution of $0.38 \mathrm{mM}\left[\mathrm{CoCp}_{2}\right]\left[\mathrm{PF}_{6}\right]$ with $20 \mathrm{mM}\left[\mathrm{NBu}_{4}{ }_{4}\right]\left[\mathrm{BF}_{4}\right]$ in scR32 at $360 \mathrm{~K}$ at $17.9 \mathrm{MPa}$ and at $50 \mathrm{mV} \mathrm{s}^{-1}$. The working electrode was a $50 \mu \mathrm{m} \varnothing \mathrm{Pt}$ disc. The reference and counter electrode were $0.5 \mathrm{~mm} \varnothing \mathrm{Pt}$ wires. The dashed line represents the estimated diffusion limited current.

Figure 12 shows voltammetry at a $1 \mathrm{~mm} \varnothing$ gold macrodisc electrode for $0.45 \mathrm{mM}\left[\mathrm{CoCp}_{2}\right]\left[\mathrm{PF}_{6}\right]$ in scR32 containing $20 \mathrm{mM}\left[\mathrm{NBu}_{4}^{n}\right]\left[\mathrm{BF}_{4}\right]$. The electrode was fitted with a baffle to reduce the effects of convection. The most noticeable features are the approximately sigmoidal shape of the voltammograms, the limited effect of changing scan rate and the absence of a cathodic current peak. These features are all consistent with the formation of a film on the electrode surface with cobaltocenium reduction proceeding through pinholes or by tunnelling through the film. The results from the micro and macro electrode experiments suggest that cobaltocenium hexafluorophosphate is not a good model redox system for use in scR32. 


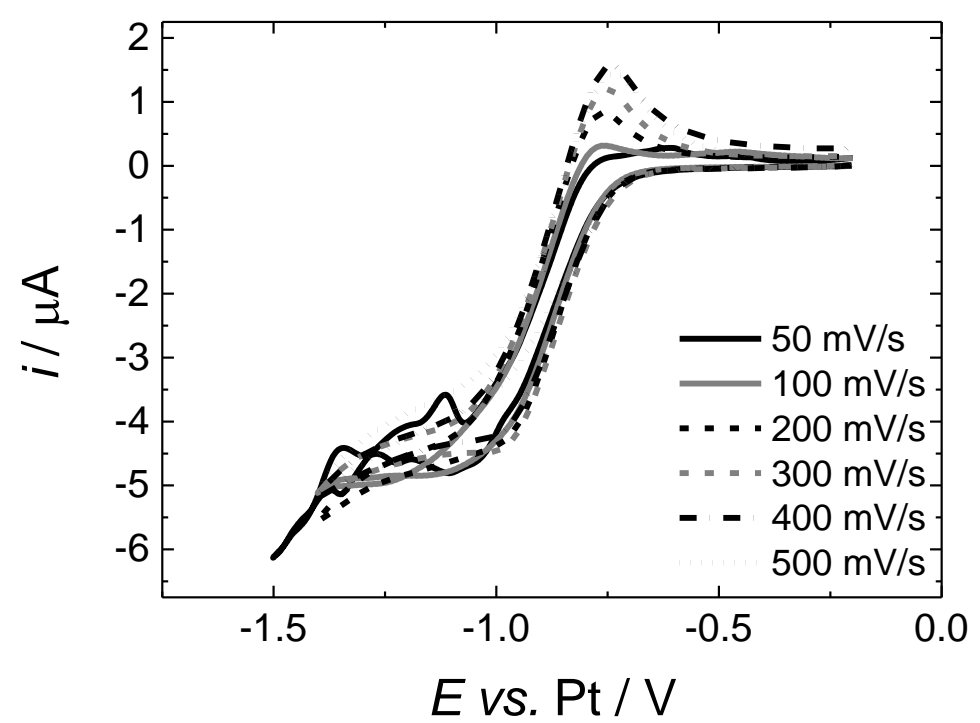

Fig. 12. Cyclic voltammograms for a solution of $0.45 \mathrm{mM}\left[\mathrm{CoCp}_{2}\right]\left[\mathrm{PF}_{6}\right]$ and $20 \mathrm{mM}\left[\mathrm{NBu}_{4}{ }_{4}\right]\left[\mathrm{BF}_{4}\right]$ in scR32 at $358 \mathrm{~K}, p \approx 14.48 \mathrm{MPa}$ for various scan rates. The working electrode was a baffled $1 \mathrm{~mm} \varnothing$ $\mathrm{Au}$ disc, the reference and counter electrode were $0.5 \mathrm{~mm} \emptyset \mathrm{Pt}$ wires.

In an attempt to overcome the problems of film formation with cobaltocenium hexafluorophosphate we also investigated the decamethylcobaltocenium cation. The electrochemistry of decamethylcobaltocenium is well behaved in liquid dichloromethane, but has a reasonably negative redox potential, around $-1.8 \mathrm{~V}$ vs. Pt. Consequently $\left[\mathrm{NBu}_{4}{ }_{4}\right]\left[\mathrm{BF}_{4}\right]$ is not a suitable supporting electrolyte for decamethylcobaltocenium electrochemistry in scR32 because the cathodic limit in this electrolyte is around $-2.0 \mathrm{~V}$ vs. Pt. We therefore changed to $\mathrm{NaBF}_{4}$ as the supporting electrolyte. However we were unable to find any evidence for reduction of the decamethylcobaltocenium cation in scR32 containing $1.02 \mathrm{mM}\left[\mathrm{DmCo}^{2}\left[\mathrm{PF}_{6}\right]\right.$ and $20 \mathrm{mM}$ [Na][BARF] at a $50 \mu \mathrm{m} \emptyset \mathrm{Pt}$ disc at $360 \mathrm{~K}$ and 17.9 $\mathrm{MPa}$ before the onset of reduction of $\mathrm{Na}^{+}$at around $-1.6 \mathrm{~V}$ vs. Pt.

\section{Conclusions}

In this work we have studied the voltammetry of three metallocenes, decamethylferrocene, cobaltocene and decamethylcobaltocene at micro and macro disc electrodes in scR32 containing 20 $\mathrm{mM}\left[\mathrm{NBu}_{4}^{\mathrm{n}}\right]\left[\mathrm{BF}_{4}\right]$ at $360 \mathrm{~K}$ and 17.6 MPa. We find that in all cases the voltammetry is distorted to some degree by the effects of random convection but that these can be supressed by adding a baffle around the electrode. These convective effects are more significant than those reported in our earlier work in $\mathrm{scCO}_{2} / \mathrm{CH}_{3} \mathrm{CN}$ [29] and we believe that this is because of the higher temperature and lower 
viscosity of the solvent. We estimate that, for our cell, the thickness of the stagnant supercritical fluid boundary layer at the electrode surface is around $35 \mu \mathrm{m}$.

Microelectrode studies show that the electrode kinetics for DMFc at platinum are fast and that the voltammetry is essentially reversible at the $50 \mu \mathrm{m}$ disc electrode. The limiting currents, corrected for random convection, obey the normal microdisc equation and are linear in electrode radius and DMFc concentration up to the highest concentration $(11 \mathrm{mM})$ used in this study. Thus, in addition, it is clear that the solubility of DMFc exceeds $11 \mathrm{mM}$ under these conditions. Decamethylferrocene is therefore shown to be an excellent choice of model redox couple for electrochemistry in scR32 at least up to $360 \mathrm{~K}$.

Based on the microelectrode studies we find that the diffusion of DMFc in scR32 containing $20 \mathrm{mM}$ $\left[\mathrm{NBu}_{4}{ }_{4}\right]\left[\mathrm{BF}_{4}\right]$ at $360 \mathrm{~K}$ and $17.6 \mathrm{MPa}$ is $8.3 \times 10^{-5} \mathrm{~cm}^{2} \mathrm{~s}^{-1}$. This value gives estimates for the viscosity of the fluid based on the Stokes-Einstein equation (assuming a hydrodynamic radius for DMFc of $0.480 \mathrm{~nm}$ ) or the Wilke-Chang equation (assuming a molar volume for DMFc of $186.6 \mathrm{~cm}^{3} \mathrm{~mol}^{-1}$ ) of 66 and $86 \mu \mathrm{Pa}$ s which are close to the value for supercritical difluoromethane at this temperature of $75 \mu \mathrm{Pa}$ s from the NIST database [43]. In comparison to the previously published results for DMFc in $\mathrm{scCO}_{2} / \mathrm{MeCN}\left(15 \mathrm{wt} \%\right.$ ) with $20 \mathrm{mM}\left[\mathrm{NBu}_{4}^{\mathrm{n}}\right]\left[\mathrm{BF}_{4}\right]$ at $309 \mathrm{~K}$ and $17.5 \mathrm{MPa}$ where the diffusion coefficient for DMFc is $4.06 \times 10^{-5} \mathrm{~cm}^{2} \mathrm{~s}^{-1}$ we find that the value in scR32 is approximately twice as big reflecting the increased temperature and lower viscosity.

Finally we have briefly investigated the voltammetry of cobaltocene and decamethylcobaltocene in scR32 under the same conditions. We find that reduction of the cobaltocenium cation leads to fouling of the Pt microdisc electrode which limits its use as a model redox system; however we estimate that the diffusion coefficient for the cobaltocenium cation is of the order of $1.0 \times 10^{-4} \mathrm{~cm}^{2} \mathrm{~s}^{-1}$, consistent with its smaller hydrodynamic radius. Preliminary studies using the decamethylcobaltocenium cation were unsuccessful and reduction did not occur within the electrolyte window (>-1.6 V vs. Pt).

\section{Acknowledgements}

This work is part of the Supercritical Fluid Electrodeposition project (www.scfed.net) which is a multidisciplinary collaboration of British universities investigating the fundamental and applied aspects of supercritical fluids funding by a Programme Grant from the EPSRC (EP/I013394/1). The authors would like to thank Dr Wenjian Zhang for his help with sublimation of materials. PNB gratefully acknowledges receipt of a Wolfson Research Merit award. 


\section{References}

[1] K.E. Toghill, M.A. Méndez, P. Voyame, Electrochemistry in Supercritical Fluids: A Mini Review, Electrochem. Commun. 44(0) (2014) 27-30.

[2] J.A. Branch, P.N. Bartlett, Electrochemistry in Supercritical Fluids, Phil. Trans. R. Soc. A 373(2057) (2015).

[3] P.N. Bartlett, D.A. Cook, M.W. George, A.L. Hector, J. Ke, W. Levason, G. Reid, D.C. Smith, W. Zhang, Electrodeposition from Supercritical Fluids, Phys. Chem. Chem. Phys. 16(20) (2014) 9202-19.

[4] P.N. Bartlett, M. Perdjon-Abel, D. Cook, G. Reid, W. Levason, F. Cheng, W. Zhang, M.W. George, J. Ke, R. Beanland, J. Sloan, The Electrodeposition of Silver from Supercritical Carbon Dioxide/Acetonitrile, ChemElectroChem 1(1) (2014) 187-194. [5] P.N. Bartlett, J. Burt, D.A. Cook, C.Y. Cummings, M.W. George, A.L. Hector, M.M. Hasan, J. Ke, W. Levason, D. Pugh, G. Reid, P.W. Richardson, D.C. Smith, J. Spencer, N. Suleiman, W. Zhang, A Versatile Precursor System for Supercritical Fluid Electrodeposition of Main-Group Materials, Chem. Eur. J. 22(1) (2016) 302-309. [6] C.Y. Cummings, P.N. Bartlett, D. Pugh, G. Reid, W. Levason, M.M. Hasan, A.L. Hector, J. Spencer, D.C. Smith, Supercritical Fluid Electrodeposition of Elemental Germanium onto Titanium Nitride Substrates, J. Electrochem. Soc. 162(14) (2015) D619-D624.

[7] C.Y. Cummings, P.N. Bartlett, D. Pugh, G. Reid, W. Levason, M.M. Hasan, A.L. Hector, J. Spencer, D.C. Smith, S. Marks, R. Beanland, Electrodeposition of Protocrystalline Germanium from Supercritical Difluoromethane, ChemElectroChem (2016) n/a-n/a.

[8] M. Atobe, H. Ohsuka, T. Fuchigami, Electrochemical Synthesis of Polypyrrole and Polythiophene in Supercritical Trifluoromethane, Chem. Lett. 33(5) (2004) 61 8-619. [9] H. Yan, T. Sato, D. Komago, A. Yamaguchi, K. Oyaizu, M. Yuasa, K. Otake, Electrochemical Synthesis of a Polypyrrole Thin Film with Supercritical Carbon Dioxide as a Solvent, Langmuir 21 (26) (2005) 12303-12308.

[10] P.E. Anderson, R.N. Badlani, J. Mayer, P.A. Mabrouk, Electrochemical Synthesis and Characterization of Conducting Polymers in Supercritical Carbon Dioxide, J. Am. Chem. Soc. 124(35) (2002) 10284-10285.

[1 1] K.E. Toghill, P. Voyame, D. Momotenko, A.J. Olaya, H.H. Girault, Steady-State Macroscale Voltammetry in a Supercritical Carbon Dioxide Medium, Phys. Chem. Chem. Phys. 15(3) (2013) 972-978.

[12] M. Gattrell, N. Gupta, A. Co, A Review of the Aqueous Electrochemical Reduction of Co2 to Hydrocarbons at Copper, J. Electroanal. Chem. 594(1) (2006) 1 19.

[13] A.P. Abbott, C.A. Eardley, Electrochemical Reduction of Co2 in a Mixed Supercritical Fluid, J. Phys. Chem. B 104(4) (2000) 775-779.

[14] G. Gritzner, J. Kuta, Recommendations on Reporting Electrode-Potentials in Nonaqueous Solvents (Recommendations 1983), Pure Appl. Chem. 56(4) (1984) 461-466.

[15] E.I. Rogers, D.S. Silvester, D.L. Poole, L. Aldous, C. Hardacre, R.G. Compton, Voltammetric Characterization of the Ferrocene Vertical Bar Ferrocenium and Cobaltocenium Vertical Bar Cobaltocene Redox Couples in Rtils, J. Phys. Chem. C 112 (7) (2008) 2729-2735.

[16] J.K. Bashkin, P.J. Kinlen, Oxygen-Stable Ferrocene Reference Electrodes, Inorg. Chem. 29(22) (1990) 4507-4509. 
[17] I. Noviandri, K.N. Brown, D.S. Fleming, P.T. Gulyas, P.A. Lay, A.F. Masters, L. Phillips, The Decamethylferrocenium/Decamethylferrocene Redox Couple: A Superior Redox Standard to the Ferrocenium/Ferrocene Redox Couple for Studying Solvent Effects on the Thermodynamics of Electron Transfer, J. Phys. Chem. B 103(32) (1999) 6713-6722.

[1 8] T. Gennett, D.F. Milner, M.J. Weaver, Role of Solvent Reorganization Dynamics in Electron-Transfer Processes - Theory Experiment Comparisons for Electrochemical and Homogeneous Electron Exchange Involving Metallocene Redox Couples, J. Phys. Chem 89(13) (1985) 2787-2794.

[19] U. Koelle, F. Khouzami, Permethylated Electron-Excess Metallocenes, Angew. Chem. Int. Ed. Engl. 19(8) (1980) 640-641.

[20] J.L. Robbins, N. Edelstein, B. Spencer, J.C. Smart, Syntheses and Electronic Structures of Decamethylmetallocenes, J. Am. Chem. Soc. 104(7) (1982) 1882-1893. [21] C.R. Cabrera, A.J. Bard, Electrochemistry in near-Critical and Supercritical Fluids. 8. Methyl Viologen, Decamethylferrocene, Os(Bpy)32+ and Ferrocene in Acetonitrile and the Effect of Pressure on Diffusion-Coefficients under Supercritical Conditions, J. Electroanal. Chem. 273(1-2) (1989) 147-160.

[22] S. Ching, J.T. McDevitt, S.R. Peck, R.W. Murray, Liquid-Phase Electrochemistry at Ultralow Temperatures, J. Electrochem. Soc. 138(8) (1991) 2308-2315.

[23] J.N. Richardson, J. Harvey, R.W. Murray, Heterogeneous Electron-Transfer Dynamics of Decamethylferrocene from 130 to 181 K, J. Phys. Chem 98(50) (1994) $13396-13402$.

[24] R.M. Crooks, A.J. Bard, Electrochemistry in near-Critical and Supercritical Fluids. 6. The Electrochemistry of Ferrocene and Phenazine in Acetonitrile between 25Degrees-C and 300-Degrees-C, J. Electroanal. Chem. 243(1) (1988) 117-131. [25] S.A. Olsen, D.E. Tallman, Voltammetry of Ferrocene in Subcritical and Supercritical Chlorodifluoromethane, Anal. Chem. 66(4) (1994) 503-509. [26] S.A. Olsen, D.E. Tallman, Conductivity and Voltammetry in Liquid and Supercritical Halogenated Solvents, Anal. Chem. 68(13) (1996) 2054-2061. [27] D.L. Goldfarb, H.R. Corti, Electrochemistry in Supercritical Trifluoromethane, Electrochem. Commun. 2(9) (2000) 663-670.

[28] D.L. Goldfarb, H.R. Corti, Diffusion of Decamethylferrocene and Decamethylferrocenium Hexafluorophosphate in Supercritical Trifluoromethane, J. Phys. Chem. B 108(10) (2004) 3368-3375.

[29] J.A. Branch, D.A. Cook, P.N. Bartlett, Electrochemical Studies of Decamethylferrocene in Supercritical Carbon Dioxide Mixtures, Phys. Chem. Chem. Phys. 17(1) (2015) 261-267.

[30] R.S. Stojanovic, A.M. Bond, Examination of Conditions under Which the Reduction of the Cobaltocenium Cation Can Be Used as a Standard Voltammetric Reference Process in Organic and Aqueous Solvents, Anal. Chem. 65(1) (1993) 5664.

[31] J.R. Aranzaes, M.C. Daniel, D. Astruc, Metallocenes as References for the Determination of Redox Potentials by Cyclic Voltammetry - Permethylated Iron and Cobalt Sandwich Complexes, Inhibition by Polyamine Dendrimers, and the Role of Hydroxy-Containing Ferrocenes, Can. J. Chem. 84(2) (2006) 288-299.

[32] J. Ke, W.T. Su, S.M. Howdle, M.W. George, D. Cook, M. Perdjon-Abel, P.N. Bartlett, W.J. Zhang, F. Cheng, W. Levason, G. Reid, J. Hyde, J. Wilson, D.C. Smith, K. Mallik, P. Sazio, Electrodeposition of Metals from Supercritical Fluids, Proc. Natl. Acad. Sci. U. S. A. 106(35) (2009) 14768-14772.

[33] P.N. Bartlett, D.C. Cook, M.W. George, J. Ke, W. Levason, G. Reid, W. Su, W. Zhang, Phase Behaviour and Conductivity Study of Electrolytes in Supercritical Hydrofluorocarbons, Phys. Chem. Chem. Phys. 13(1) (2011) 190-198. 
[34] P.R. Birkin, S. SilvaMartinez, A Study of the Effect of Ultrasound on Mass Transport to a Microelectrode, J. Electroanal. Chem. 416(1-2) (1996) 127-138. [35] C. Amatore, S. Szunerits, L. Thouin, J.S. Warkocz, The Real Meaning of Nernst's Steady Diffusion Layer Concept under Non-Forced Hydrodynamic Conditions. A Simple Model Based on Levich's Seminal View of Convection, J. Electroanal. Chem. 500(1-2) (2001) 62-70.

[36] C. Amatore, C.c. Pebay, L. Thouin, A. Wang, J.S. Warkocz, Difference between Ultramicroelectrodes and Microelectrodes: Influence of Natural Convection, Anal. Chem. 82(16) (2010) 6933-6939.

[37] M.V. Mirkin, A.J. Bard, Simple Analysis of Quasi-Reversible Steady-State Voltammograms, Anal. Chem. 64(19) (1992) 2293-2302.

[38] P.N. Bartlett, D.C. Cook, M.W. George, J. Ke, W. Levason, G. Reid, W.T. Su, W.J. Zhang, Phase Behaviour and Conductivity Study on Multi-Component Mixtures for Electrodeposition in Supercritical Fluids, Phys. Chem. Chem. Phys. 12(2) (2009) $492-$ 501.

[39] G. Denuault, M.V. Mirkin, A.J. Bard, Direct Determination of DiffusionCoefficients by Chronoamperometry at Microdisk Electrodes, J. Electroanal. Chem. 308(1-2) (1991) 27-38.

[40] M. Matsumoto, T.W. Swaddle, The Decamethylferrocene(+/0) Electrode Reaction in Organic Solvents at Variable Pressure and Temperature, Inorg. Chem. 43(8) (2004) 2724-2735.

[41] P.R. Sassiat, P. Mourier, M.H. Caude, R.H. Rosset, Measurement of DiffusionCoefficients in Supercritical Carbon-Dioxide and Correlation with the Equation of Wilke and Chang, Anal. Chem. 59(8) (1987) 1164-1170.

[42] D. Tran, J.P. Hunt, S. Wherland, Molar Volumes of Coordination-Complexes in Nonaqueous Solution - Correlation with Computed Vanderwaals Volumes, Crystal Unit-Cell Volumes, and Charge, Inorg. Chem. 31(12) (1992) 2460-2464.

[43] P.J. Linstrom, W.G. Mallard, Thermophysical Properties of Fluid Systems. <http://webbook.nist.gov/chemistry/fluid/>, 2016 (accessed 28.06.16.).

[44] A.P. Abbott, E.G. Hope, D.J. Palmer, Effect of Solutes on the Viscosity of Supercritical Solutions, J. Phys. Chem. B 111 (28) (2007) 8114-8118.

[45] A.A.J. Torriero, J. Sunarso, M. Forsyth, C. Pozo-Gonzalo, Assessment of Permethylated Transition-Metal Sandwich Complexes as Internal Reference Redox Systems in Ionic Liquids, Phys. Chem. Chem. Phys. 15(7) (2013) 2547-2553. 